\title{
A BACTERIOLOGICAL STUDY OF MITHI RIVER WATER IN MUMBAI
}

\section{METROPOLIS}

\author{
Aarti S. Nagarsekar and Umesh B. Kakde
}

Govt. Of Maharashtra's Ismail Yusuf College, Jogeshwari (E), Mumbai Corresponding author Email : aarti.nagarsekar@gmail.com

\begin{abstract}
:
Water plays a very important role in sustaining life. The quality of water acts as a barometer of the environmental health and well being of the human society. In the last 3 to 4 centuries, urbanization and industrialization have progressed affecting water bodies, which are being generally used for discharging domestic and industrial wastes. The river water pollution has an adverse effect on the environmental health and hygiene of people in surrounding areas of the river. It also affects the river water ecosystem. In order to assess the Bacteriological quality of Mithi River water, four sampling stations along the course of the Mithi River were selected. The sampling points were selected so as to ensure substantial bacteriological pollution. Anthropological factors, namely, dense population, a number of housing colonies and slums near the sampling points contributed to the heavy pollution. Three Bacteriological parameters namely, Total Heterotrophic Bacteria, Total Coliform and Fecal Coliform were evaluated. It was observed that these parameters, indicating water quality, substantially exceeded the limits specified by various bodies for domestic consumption of water. This was due to the heavy discharge of sewage from the nearby residential units/slums. The River water was therefore heavily polluted. A mechanism for the continuous monitoring of the river water and efforts to control discharge of sewage in the Mithi River are required.
\end{abstract}

\section{Keywords:}

Bacteriological parameters, Water pollution, Mithi River, Mumbai, environmental health, hygiene, aquatic life.

\section{Introduction:}

Water is essential to life on Earth. The importance of clean water was known from the ancient times. As civilization progressed man invented new techniques to exploit river systems. With the advent of industrialization, the number of towns, cities began to grow rapidly. Regions having dense population, residential units, and slums etc. sprung up around Industrial Units and 
Factories, since a source of livelihood was provided to people living nearby. The river systems were seen as convenient and cheap way to dispose of these domestic wastes. This had an adverse effect on human health and environment. Though not specifically intended, the process of development vide, urbanization, globalization and industrialization leads to an adverse effect on the ecosystem (Tanner et al., 2001). In both developing and developed countries, the disposal of human wastes is a great challenge (Zimmel et al., 2004). Natural sources of water have an inbuilt process to purify water to a certain extent through physical, chemical and biological means. However, these processes cannot handle excess of pollutants which are being discharged into the water bodies. Over population and related human activities like industrialization, deforestation etc. cause a change in the delicate water balance (Trivedi et al., 1989-90). In India, clean drinking water is available to only $12 \%$ of the people. The rest have to use polluted sources of water, which causes diseases, health \& hygiene problems (Trivedi et al., 2004). The importance of clean drinking water cannot but be overemphasized. Efforts to reduce Water pollution have therefore become a global phenomenon. Point sources of pollution refer to discharge of wastes into water bodies directly by Industrial Units, domestic sewage plants etc. Non point sources refer to indirect pollutants, such as, impurities which settle form air, farm water runoff etc. It is very difficult to indentify non point sources and their remediation is very costly (Harnova et al., 2003). There is an abundance of literature on "Water Quality" of various water bodies, since the problem of "water pollution" has now become a global phenomenon. However, utmost care needs to be taken to ensure that water of adequate quality and in sufficient quantity is provided to the people for domestic and industrial purposes. Due to increase in human population and growth of industries there is a considerable pressure on water bodies; the pollution level are increasing (Sahu et al., 1991). Various anthropogenic activities like the discharge of domestic wastes, industrial effluents, recreational and municipal 
physiochemical properties of river waters (Panda et al., 1991). The use of untreated waste water for irrigational purposes has increased, as a result of lack of good quality of water. The fast reducing availability pure water for domestic or industrial purposes, coupled with its unequal distribution globally, has become a major concern in terms of Management of water quality and quantity (Leonard et al., 1971). Ecological damage and a serious health hazard are mainly a result of deterioration in the quality of water which is mainly due to human activities, such as, discharge of industrial/domestic wastes, sewage , agricultural run offs, disposal of dead bodies etc. (Meitei et al., 2004). The fecal pollution in water is revealed by quantifying colonies of "Coliform group". As such, it serves as a critical parameter while assessing the quality of water. This has also focused attention on improving "concept of public health". Though Coliform bacteria show fecal pollution in water; their presence in water does not imply that the quantitative degree of fecal pollution or the presence of pathogenic microorganisms is ascertained. The Coliform group mainly includes Bacterial Species of known excretal origin. In particular, Escherichia coli, fecal streptococci and Clostridium perfringens are members of the "Coliform group", which is considered as common organisms indicating fecal pollution. Enteric pathogens are most frequently encountered among the different pathogens disseminated in different water sources. It is imperative to strictly monitor and reduce as far as possible, both types of waste -residential and industrial which contributes to fecal pollution in water.

\section{Material and Method:}

Area of Study The Mithi River flows through the heart of Mumbai City, which is a Metro and a premier city of India. The river has by now become synonymous with all ills which a river may experience. Encroachment of flood plains, storm water drainage, and disposal of untreated sewage and dumping of liquid \& solid wastes are the various ills which afflict the River. The hills in the "Sanjay Gandhi National Park", which are at an altitude of 246 Meters above sea level, 
are the originating place of the River. Thereafter it merges with the overflows of Tulsi, Powai and Vihar lakes and travels downstream for around $18 \mathrm{Kms}$ up to Mahim Bay. All the thickly populated areas like the residential and industrial complexes of Powai, Saki Naka, Kurla, Bandra- Kurla complex and Mahim lie on its path. In its initial stretches the river is narrow, but near the Bandra Kurla Complex it is at its widest. Further, it has a rather steep gradient in its initial stretches, and hence the water flows quite fast. However, on its second leg (say after Andheri), it course goes through a flat region. As a result of this, water and waste accumulate. The picture showing the flow of Mithi River, from origin to destination, is given below: Figure 1: MITHI RIVER FROM ORIGIN TO DESTINATION (Source: National Environment Engineering research Institute Report - 2011.) Sampling points: The process of evaluating the quality of water along the course of Mithi River was carried out by selecting four sampling points along its path. A brief description of the location and the topographical details of each point are given below: Sr. Description of sampling point Latitude Longitude Remarks S1 Airport- Bridge on road from LBS Marg to IA colony (road from behind airport.) 19.08 72.87 Heavy residential area, slums- Airport Waste discharged. S2 Safed pool 19.09 72.88 Slums, unauthorized industrial units S3 CST Bridge 19.0772 .88 Thickly populated area. Unauthorized industrial units S4 Kalanagar Bridge 19.05 72.85 Area surrounded by mangr oves, acting as city"s oxy-gen lungs. Near "Saleem Ali" bird sanctuary. Bacterial Analysis Technique Membrane filtration technique as per standard Methods (APHA, 1998) and WHO guidelines (WHO, 1985) was adopted. Membrane filter pore size $0.45 \mu$ and $47 \mathrm{~mm}$ diameter were used. Media used were - HiMedia MEndo broth for total coliforms and M-FC agar for faecal coliforms. The filter, through which required concentration of sample to be analysed has been passed, is placed on the absorbent pad with selected media and the petridish containing the above filter is then incubated. Incubation temperature and time taken for total coliform was $35 \pm 0.5^{\circ} \mathrm{C}$ for $24 \mathrm{hrs}$ and $44.5 \pm 0.2{ }^{\circ} \mathrm{C}$ for $24 \mathrm{hrs}$ for faecal coliform. The two media commonly used are "m-Endo-type media" 
and Tergitol-TTC in North America (APHA 1998) and in Europe (AFNOR, 1990) respectively. Autoclave sterilized dilution water prepared from potassium dihydrogen phosphate (34 gms in 1ltr) is used for making required concentrations of the sample. After incubation, red (magenta) coloured colonies with metallic (green gold) surface sheen developed for total Coliform and blue coloured colonies developed for faecal Coliform. Total and faecal Coliform count was computed as Coliform colonies counted/ml sample filtered X 100 and expressed as total or faecal Coliforms nos per $100 \mathrm{ml}$. Serial Dilution Method technique: Used for the analysis of total heterotrophic bacterial counts. The plate count method is used for ascertaining heterotrophic bacterial counts. It consists of growing bacteria colonies on a "plate" using a specific kind of nutrients. These bacteria colonies can be seen without any optical aids and can also be counted. In order for this method to be of any use, the dilution of the original sample has to be properly carried out. One of the requirements relate to the number of colonies of the required bacteria that should be grown.

Ideally, this number should range between (say) $30-300$. If the number is less than 30 then the procedure becomes statistically unstable. If the number is more than 300 then there is overlapping in the counting of these colonies and hence the count tends to become incorrect. In order to ensure that the correct number of colonies is grown arrangements may have to be made to the sample several times. In the present case, several serial dilutions of the samples of the scale $(1: 10,1: 100,1: 1000$ etc.) were made. Sterile water was used and the required bacterium was grown on nutrient agar (NA) media in a plate/dish. The plate was sealed and then incubated at the required temperature. The temperature of $37 \mathrm{oC}$ was followed. The process of counting was conducted at the end of the incubation period.

\section{Result and Discussion:}

Total Bacteria, Total Coliform \& Fecal Coliforms The Table 1, Table 2 and Table 3 show the seasonal averages for post-monsoon, pre-monsoon and monsoon 
seasons and the 12 monthly values showing the count of Total Bacteria, Total Coliform and Fecal Coliform. Figure 1, Figure 2 and Figure 3 show the seasonal fluctuations for Total Bacteria; Total Coliform and Fecal Coliform at each of the sampling points. Bacteriological Analysis Studies have revealed that a large number of "Coliform bacteria" are present in the intestines of humans as well as other warm-blooded animals. They are therefore found in the sewage discharged from residential units. As a result the "Coliform Bacteria" may be found in greater numbers than other disease causing bacteria. Therefore, when such Coliform colonies are found in rivers, lakes or other water bodies, they serve as kind of indicators that other disease causing bacteria may be present in various water environments. However, the correlation between the potential existence of enteric pathogens in aquatic systems and the measure of high count of "Coliform Bacteria" in water has been a subject of great disagreements for many years. It has been observed that there were several cases of outbreak of diseases from waters meeting the Coliform requirements (Moore et al., 1994; MacKenzie et al., 1994; Gofti et al., 1999). Two methods are used for ascertaining sample count of these bacteria. Historically, two methods are available for E-coli analysis in water or environmental samples. According to a study (Agarwal et al., 2010), the number of total Coliform was observed to be maximum in the months of April \& June and minimum in January. Average total Coliform was observed to be highest in mid-monsoon, followed by premonsoon and the lowest in winter. The season wise/month wise data for TBC for water samples collected at four sampling points is given in the Table 1. In a study carried out it was observed that the "Coliform Bacteria" cannot survive in clean waters beyond particular period of time. The existence of such bacteria has to be regarded as pointer of high level of pollution (Hiraishi et al., 1984). The observed variation in coliform bacterial count was due to seasonal changes (Legendra et al., 1984). Fecal pollution is a primary source of waterborne pathogens (Dwight et al., 2005). Bacterial contamination leads to diseases like typhoid, diarrhea, dysentery, gastroenteritis, paratyphoid etc. as many of these 
bacteria are pathogenic (Kumar et al., 2006). Bacteria are the chief decomposers and indicators of organic pollution. Bacteria count is affected by seasonal variation. Usually, in winter, lesser concentration is observed due to low temperature and low input of organic matter. In their study a direct variation was observed, between "water quality" as indicated "Coliform Bacteria" count and "gastrointestinal diseases" (Baron et al., 1982). A statistical analysis was carried out for Total Bacteria Count, Total Coliform Count and Fecal Coliform count. An "ANNOVA" test was carried out using the data for each parameter. The hypothesis selected for the test that "There is no significant variation". The tabulated values of $F$ at $5 \%$ level of significance, F 2, $6=5.14$ and F 3, $6=4.75$ were obtained. If the calculated value of $\mathrm{F}$ is more than the tabulated value, the null hypothesis is rejected that means there is significant variation. Alternatively, if the calculated value of $\mathrm{F}$ is less than the tabulated value, the null hypothesis is accepted. This implies that there is no significant variation in the data. In the present investigation, it was observed that there was a significant location wise and season wise variation in Total Bacteria Count. In case of Total Coliform and Fecal Coliform count no significant variation was observed between two locations or two seasons. Water samples from all the sampling stations collected throughout the study periods were heavily contaminated with total Coliform, fecal Coliform and total heterotrophic bacteria. The total heterotrophic bacterial counts were ranged between 107 - $109 \mathrm{CFU} / \mathrm{ml}$ of water sample. The count of total Coliform was substantially more than the permissible limit is about $500 \mathrm{CFU} / 100 \mathrm{ml}$ of water. The maximum counts were recorded during summer season than the winter and monsoon. The fecal Coliform count generally ranged between 2000 - $7000 \mathrm{CFU} / 100 \mathrm{ml}$ of the sample.

\section{Conclusion:}

It is revealed from the results that the concentration levels for several physiochemical parameters have exceeded the maximum permissible limits. It 
can therefore be concluded that the waters of the Mithi River are substantially polluted due to various pollutants. Therefore, the water cannot be used for any domestic or industrial purposes. Several adverse effects are caused by the polluted water of the "River" on the health $\&$ hygiene of the people staying in adjoining areas near the river. It is also ecologically damaging the aquatic life of the River and the Arabian Sea besides it also going to affect the mangrove ecosystem which serves the lungs of the city and Saleem Ali bird sanctuary at Mahim, where migratory birds come for nesting is nearby. Therefore a mechanism for continuous monitoring of the quality of the water of river Mithi is required. Also concentrated efforts are required from all concerned to reduce dumping of industrial and residential wastes in the river waters. The State Government, Municipal Authorities need to work together to achieve this. Broadly, the following suggestions are made to reduce pollution levels in the Mithi River. a) Strict controls need to be introduced on the disposal of domestic sewage by Housing Societies and residential units. There are many sewage lines which dispose the sewage in the river. The sewage should be treated and then only allow to dispose off. b) Dumping of garbage into the river should be strictly prohibited. c) Strict implementation of all the Environmental laws to be followed. d) Modern sanitation systems should be adopted. Proper lavatories need to be built at different locations to prevent open defecation. e) The width of the Mithi River needs to be widened by relocating residential, commercial units, slums which obstruct the course of the river.

\section{Reference:}

Agarwal A.K. and Rozgar G.R. (2010). Physicochemical \& microbiological study of Tehri dam reservoir - Garhwal Himalaya, India -Journal of American Science, 6

American Public Health Association, Washington DC, 10 edition 1985 
APHA (1998): Standard Methods for the examination of water and waste water. 20th Ed. Washington D.C, USA, pp 9-56, 9.47 to 9.53

Baron R.C., Murphy F.D., Greenberg H.B., Davis C.E., Bregman D.J., Gary G.W (1982). Norwalk Gastrointestinal illness, an outbreak associated with swimming in recreational lake and being secondary person for transmission American Journal Epidemial 115, 163-172

Dwight R.H., Fernandes L.M., Baker D.B., Semezad J.C. and Plson B.H. (2005).

Estimating the economic burden from illness associated with recreational coastal water pollution- a case study in Orange County, California, Journal of Envioronment Management, 76 pp 95-103

Gofti, L., Zmirou, D., Murandi, F.S., Hartemann, P., Poleton, J.L. (1999).

Waterborne microbiological risk assessment: a state of the art and perspectives. Rev. Epidemiol. Sante' Publi. 47, 61-75.

Harnova R. K. (2003). Nutrient Variation in the Urban Drainage water of Harare, Zimbabwe - assessment of regularity aspects, Diffuse Pollution, Dublin.

Kumar, S. S., Puttaiah, E. T., Manjappa, S., Naik S. P., and Kumara V. (2006). Water quality assessment of river Tunga, Karnataka, Environment and Ecology 24(1), 23-26

Leonard, L.C. (1971). Water and Water Pollution Vol 1, Marcel Dekkar Inc., New York

MacKenzie, W.R., Hoxie, N.J., Proctor, M.E., Gradus, M.S., Blair, K.A., Peterson, D.E., Kazmierczak, J.J., Addiss, D.G., Fox, K.R., Rose, J.B.L., (1994). A massive outbreak in Milwaukee of Cryptosporidium infection transmitted through the public water supply. N. Engl. J. Med. 331, 161167. 
Meitei N.S., P.M. Patil (2004). Water Quality of Purna River in Puna town in Maharashtra Journal of Aqua Biology 19, 77-78.

Moore, A.C., Herwaldt, B.L., Craun, G.F., Calderon, R.L., Highsmith, A.K., Juranek, D.D. (1994). Waterborne disease in the United States, 1991 and 1992. J. AWWA 86, 87- 99.

National Environmental Engineering research Institute- January (2011). - A report Current status of Mithi River and possible solutions.

Panda R.B., Sahu B.K., Sinha B.K., and Nayak A. (1991). A comparative study and diurnal variation of Physiochemical Characterics of River, Well and Pond Water at Rourkela Industrial Complex of Orissa J. Ecotoxical Environment monitoring (3) 206-217.

Sahu B.K. (1991). studies of aquatic pollution load in the River Brahmani PhD thesis, Sambalpur University

Tanner C. C (2001), Plants as ecosystem engineers in subsurface-flow treatment wetlands, Water Science and Technology 44(11-12), 9-17

Trivedi P.R. 1989-90, “Envioronmental Impact Assessment” Encyclopaedia of Indian Environment (Volume II)

Trivedi P.R. (2004) - India"s Environment, APH Publishing Company, New Delhi

WHO (1985): Guidelines for Drinking Water Quality. Vol 3. pp 108-115

Zimmel Y., Kirzhner F., and Roitman S. (2004), Use of Naturally growing aquatic plants for waste water purification, Water Environment Research 76(3), 220-230 
Table 1: The month wise/season wise data of Total Bacteria Count (CFU/ ml)

\begin{tabular}{|l|c|c|c|c|}
\hline Sampling Stations/ MONTHS & Airport & Safed Pool & CST bridge & Kalanagar \\
\hline October-11 & 2179562 & 8162413 & 6291871 & 1172896 \\
\hline November-11 & 1985673 & 10213218 & 4873986 & 1931421 \\
\hline December-11 & 1934652 & 9347632 & 3982483 & 2283923 \\
\hline Janaury-12 & 1872915 & 6231845 & 4132913 & 1835358 \\
\hline Post Monsoon (average ) & $\mathbf{1 9 9 3 2 0 1}$ & $\mathbf{8 4 8 8 7 7 7}$ & $\mathbf{4 8 2 0 3 1 3}$ & $\mathbf{1 8 0 5 9 0 0}$ \\
\hline February-12 & 1529374 & 3981421 & 4183612 & 986286 \\
\hline March-12 & 3685419 & 9412346 & 18329713 & 1136276 \\
\hline April-12 & 7432521 & 12372152 & 10728137 & 2762517 \\
\hline May-12 & 9612432 & 18152176 & 21897198 & 7162519 \\
\hline Pre Monsoon (average ) & $\mathbf{5 5 6 4 9 3 7}$ & $\mathbf{1 0 9 7 9 5 2 4}$ & $\mathbf{1 3 7 8 4 6 6 5}$ & $\mathbf{3 0 1 1 9 0 0}$ \\
\hline June-12 & 1785321 & 9563481 & 10672145 & 586217 \\
\hline July-12 & 323039 & 6432432 & 7341670 & 397769 \\
\hline August-12 & 256457 & 528986 & 5812361 & 468697 \\
\hline September-12 & 478931 & 4731298 & 6938513 & 696697 \\
\hline $\begin{array}{l}\text { Monsoon } \\
\text { (average values) }\end{array}$ & $\mathbf{7 1 0 9 3 7}$ & $\mathbf{5 3 1 4 0 4 9}$ & $\mathbf{7 6 9 1 1 7 2}$ & $\mathbf{5 3 7 3 4 5}$ \\
\hline Minimum (monthly) & 265457 & 528986 & 4132913 & 397769 \\
\hline Maximum (monthly) & 9612462 & 18152176 & 21897198 & 7162519 \\
\hline Mean & $\mathbf{2 7 5 6 3 5 8}$ & $\mathbf{8 2 6 0 7 8 3}$ & $\mathbf{8 7 6 5 3 8 3}$ & $\mathbf{1 6 2 5 0 4 8}$ \\
\hline
\end{tabular}

Table 2: The month wise/season wise data Total Coliform for water samples

\begin{tabular}{|l|c|c|c|c|}
\hline Sampling Stations/ MONTHS & Airport & Safed Pool & CST Bridge & Kalanagar \\
\hline October-11 & 93287 & 115236 & 108512 & 34612 \\
\hline November-11 & 96894 & 168437 & 98176 & 41923 \\
\hline December-11 & 97246 & 98257 & 89256 & 39815 \\
\hline Janaury-12 & 78235 & 102318 & 49176 & 14313 \\
\hline Post Monsoon (average ) & $\mathbf{9 1 4 1 5}$ & $\mathbf{1 2 1 0 6 2}$ & $\mathbf{8 6 2 8 0}$ & $\mathbf{3 2 6 6 6}$ \\
\hline February-12 & 61126 & 91489 & 53458 & 31510 \\
\hline March-12 & 186247 & 201631 & 191716 & 29557 \\
\hline April-12 & 236185 & 176896 & 681586 & 44513 \\
\hline May-12 & 389348 & 215318 & 1123762 & 92417 \\
\hline Pre Monsoon (average) & $\mathbf{2 7 0 5 9 3}$ & $\mathbf{1 7 1 3 3 3}$ & $\mathbf{5 1 2 6 3 0}$ & $\mathbf{4 9 4 9 9}$ \\
\hline June-12 & 86617 & 78172 & 1053126 & 8193 \\
\hline July-12 & 89123 & 39183 & 49461 & 7613 \\
\hline August-12 & 71058 & 17261 & 41213 & 6521 \\
\hline September-12 & 98512 & 67923 & 38427 & 11554 \\
\hline $\begin{array}{l}\text { Monsoon } \\
\text { (average values) }\end{array}$ & $\mathbf{8 6 3 2 7}$ & $\mathbf{5 0 6 3 4}$ & $\mathbf{2 9 5 5 5 7}$ & $\mathbf{8 4 7 0}$ \\
\hline Minimum (monthly) & 61126 & 17261 & 38427 & 6521 \\
\hline Maximum (monthly) & 389348 & 215318 & 1123762 & 92417 \\
\hline Mean & $\mathbf{1 4 9 4 4 5}$ & $\mathbf{1 1 4 3 4 3}$ & $\mathbf{2 9 8 1 5 5}$ & $\mathbf{3 0 2 1 1}$ \\
\hline
\end{tabular}


Table 3: The month wise/season wise data Fecal Coliform Count (CFU/100 ml) for water samples

\begin{tabular}{|l|c|c|c|c|}
\hline Sampling Stations/ MONTHS & Airport & Safed Pool & CST bridge & kalanagar \\
\hline October-11 & 5989 & 5231 & 5317 & 1618 \\
\hline November-11 & 7194 & 7198 & 4219 & 1439 \\
\hline December-11 & 5076 & 3987 & 3196 & 1107 \\
\hline Janaury-12 & 4512 & 4891 & 2857 & 925 \\
\hline Post Monsoon (average ) & $\mathbf{5 6 9 3}$ & $\mathbf{5 3 2 6}$ & $\mathbf{3 8 9 7}$ & $\mathbf{1 2 7 2}$ \\
\hline February-12 & 2615 & 3189 & 1917 & 2104 \\
\hline March-12 & 7961 & 7931 & 7516 & 1853 \\
\hline April-12 & 6158 & 5189 & 3897 & 3246 \\
\hline May-12 & 7439 & 8947 & 31962 & 7123 \\
\hline Pre Monsoon (average ) & $\mathbf{4 5 1 2}$ & $\mathbf{6 3 1 4}$ & $\mathbf{1 1 3 2 3}$ & $\mathbf{3 5 8 1}$ \\
\hline June-12 & 2813 & 2153 & 46891 & 700 \\
\hline July-12 & 1957 & 1713 & 2651 & 695 \\
\hline August-12 & 1562 & 891 & 1996 & 714 \\
\hline September-12 & 1893 & 2893 & 1871 & 709 \\
\hline $\begin{array}{c}\text { Monsoon } \\
\text { (average values) }\end{array}$ & $\mathbf{2 0 5 6}$ & $\mathbf{1 9 1 2}$ & $\mathbf{1 3 3 5 2}$ & $\mathbf{7 0 4}$ \\
\hline Minimum (monthly) & 1562 & 891 & 1871 & 700 \\
\hline Maximum (monthly) & 7961 & 7931 & 46891 & 7123 \\
\hline Mean & 4087 & 4517 & 9524 & 1852 \\
\hline
\end{tabular}

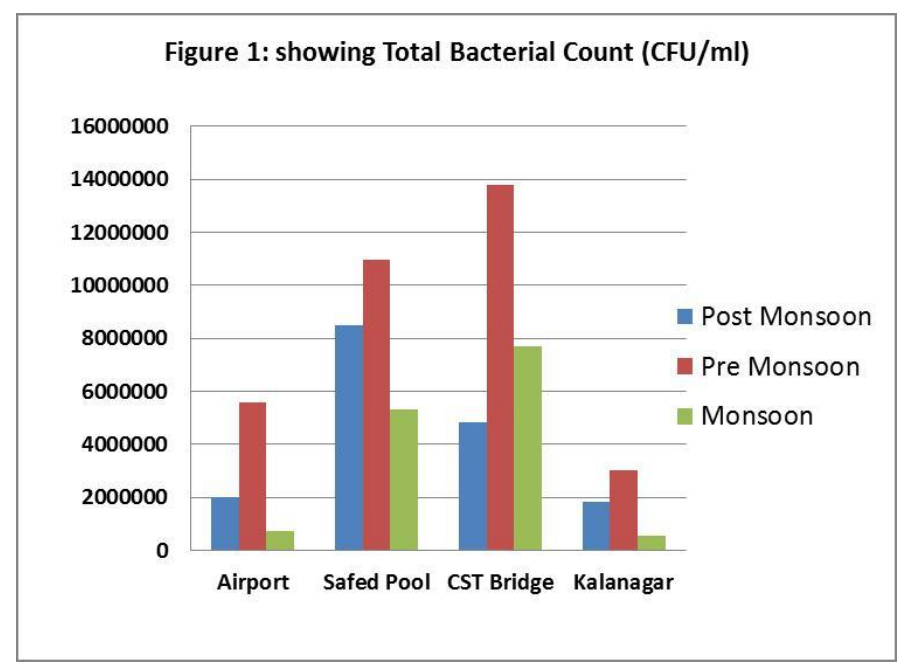



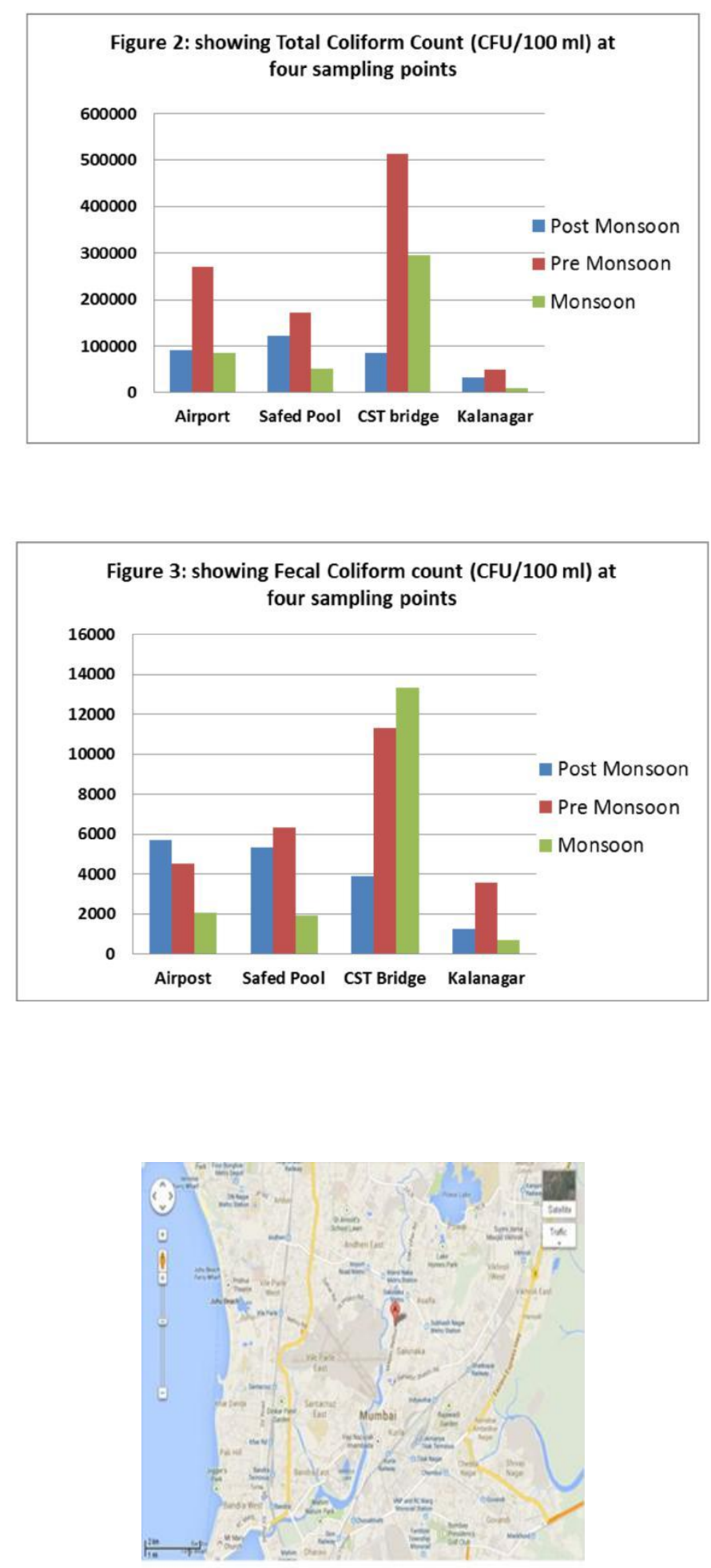

Figure 2: Mithi river from its origin to distination

(Source: National Environment Engineering research Institute Report - 2011.) 